J. Lake Sci. (湖泊科学) , 2015, 27(5):799-810

DOI $10.18307 / 2015.0506$

(C) 2015 by Journal of Lake Sciences

\title{
滇池水一沉积物界面磷形态分布及潜在释放特征"
}

\author{
何 佳 $^{1}$, 陈春瑜 ${ }^{1}$, 邓伟明 ${ }^{1}$, 徐晓梅 ${ }^{1 * *}$, 王圣瑞 ${ }^{2}$, 刘文斌 ${ }^{2}$, 吴 雪 $^{1}$, 王 丽 $^{1}$ \\ ( 1 : 昆明市环境科学研究院, 昆明 650032$)$ \\ (2: 中国环境科学研究院湖泊生态环境创新基地,国家环境保护湖泊污染控制重点实验室,北京 100012)
}

\begin{abstract}
摘 要: 通过现场调查和室内模拟实验, 对滇池 35 个上覆水一沉积物磷的分布特征以及沉积物中磷释放动力学特征进行研 究,结果表明:滇池表层沉积物中不同形态磷含量表现为:有机磷 $(\mathrm{OP})(1482.49 \pm 1156.82 \mathrm{mg} / \mathrm{kg})>$ 钻结合态磷 $(\mathrm{Ca}-\mathrm{P})$ $(865.54 \pm 558.40 \mathrm{mg} / \mathrm{kg})>$ 金属氧化物结合态磷 $(\mathrm{Al}-\mathrm{P})(463.77 \pm 662.18 \mathrm{mg} / \mathrm{kg})>$ 残渣态磷 $(\mathrm{Res}-\mathrm{P})$ $(218.52 \pm 83.11 \mathrm{mg} / \mathrm{kg})>$ 可还原态磷 $(\mathrm{Fe}-\mathrm{P})(128.13 \pm 101.56 \mathrm{mg} / \mathrm{kg})>$ 弱吸附态磷 $\left(\mathrm{NH}_{4} \mathrm{Cl}-\mathrm{P}\right)(2.26 \pm 3.05 \mathrm{mg} / \mathrm{kg})$; 滇池上覆 水草海总磷浓度处于劣 $\mathrm{V}$ 类水平, 外海不同湖区总磷浓度介于 $\mathrm{V} \sim \mathrm{V}$ 类之间; 滇池水体中的磷以颗粒态磷含量最高; 滇 池表层沉积物中磷的释放是由快反应和慢反应两部分组成. 释放过程主要发生在前 $8 \mathrm{~h}$ 内; 不同区域沉积物磷的最大释 放速率、最大释放量、磷的释放潜力平均值均表现为: 草海 $>$ 外海北部 $>$ 外海南部 $>$ 湖心区; 滇池表层沉积物中磷的释放 主要由 $\mathrm{NH}_{4} \mathrm{Cl}-\mathrm{P} 、 \mathrm{Fe}-\mathrm{P} 、 \mathrm{Al}-\mathrm{P}$ 和 $\mathrm{OP}$ 进行, 其中, $\mathrm{NH}_{4} \mathrm{Cl}-\mathrm{P}$ 和 $\mathrm{Fe}-\mathrm{P}$ 所占比重较大; 磷的释放与上覆水中溶解性总磷、溶解态 无机磷和溶解态有机磷呈显著正相关, 预示着上覆水中磷的迁移转化更多地受到水一沉积物界面浓度梯度的控制, 进一 步说明不能以总磷含量来评价湖泊磷素释放的状况, 需与磷形态及分布特征相结合进行分析.
\end{abstract}

关键词: 滇池; 磷; 沉积物; 上覆水; 磷形态; 磷释放

\section{Distribution and release characteristics of phosphorus in water-sediment interface of Lake Dianchi}

HE Jia $^{1}{ }$, CHEN Chunyu ${ }^{1}$, DENG Weiming ${ }^{1}$, XU Xiaomei $^{1}$, WANG Shengrui ${ }^{2}$, LIU Wenbin ${ }^{2}$, WU Xue ${ }^{1} \&$ WANG $\mathrm{Li}^{1}$

(1: Kunming Institute of Environmental Science, Kunming 650032, P. R. China)

(2: State Environmental Protection Key Laboratory for Lake Pollution Control, Research Center for Lake Eco-environment, Chinese Research Academy of Environment Sciences, Beijing 100012, P. R. China)

Abstract: The distribution status and release characteristics of phosphorus were investigated by studying the lease kinetics characteristics and phosphorus forms from thirty-five sediment samples collected in Lake Dianchi. Results indicated that: The rank order of phosphorus contents in the surface sediment of Lake Dianchi was organic P( OP) (1482.49 $\pm 1156.82 \mathrm{mg} / \mathrm{kg})>\mathrm{calcium}-\mathrm{bound}$ $\mathrm{P}(\mathrm{Ca}-\mathrm{P})(865.54 \pm 558.40 \mathrm{mg} / \mathrm{kg})>$ metal oxide-bound $\mathrm{P}(\mathrm{Al}-\mathrm{P})(463.77 \pm 662.18 \mathrm{mg} / \mathrm{kg})>\mathrm{residual} \mathrm{P}(\mathrm{Res}-\mathrm{P})(218.52 \pm$ $83.11 \mathrm{mg} / \mathrm{kg})>$ Fe-bound $\mathrm{P}(\mathrm{Fe}-\mathrm{P})(128.13 \pm 101.56 \mathrm{mg} / \mathrm{kg})>$ weakly absorded $\mathrm{P}\left(\mathrm{NH}_{4} \mathrm{Cl}-\mathrm{P}\right)(2.26 \pm 3.05 \mathrm{mg} / \mathrm{kg})$; The amount of total phosphorus in overlying water exceed V class in Caohai and between Class IV and Class V in other sections. The amount of particulate $\mathrm{P}(\mathrm{PP})$ is the highest among total phosphorus ( TP) ; The process of phosphate release from the surface sediment to the water in Lake Dianchi mainly occurred in the first $8 \mathrm{~h}$ and the kinetics were divided into the rapid-stage and the slowstage. The rank order of mean values of maximal phosphorus adsorption rate $\left(V_{\max }\right)$, maximal phosphours adsorption capacities $\left(Q_{\max }\right)$, the release potential of sedimentary phosphorus ( IDE-P) were Caohai $>$ northern coast $>$ southern coast $>$ lake center; From the correlation parameters, phosphorus release can be inferred to obtain the contribution degree of different forms of phosphorus on release potential of phosphorus in the sediments of Lake Dianchi. Therefore, the evaluation of sediment phosphorus release

* 国家水体污染控制与治理科技重大专项(2012ZX07102) 和“蓝藻代谢与滇池化学需氧量的关系和原因”研究项目 (2013-04-04-A-S-01-3123) 联合资助. 2014-10-09 收稿;2014-12-19 收修改稿. 何佳 (1983 ), 女, 硕士, 工程 师;E-mail:dcszxb@163.com.

** 通信作者;E-mail:deszxb@163.com. 
risk should not be only limited to the analyse of the basic physical and chemical properties. Great attention should be paid to the contents of different forms of phosphorus content and their proportions of total phosphorus.

Keywords: Lake Dianchi; phosphorus; sediments; overlying water; forms of phosphorus; phosphorus release

水一沉积物界面是环境中水相和沉积相之间的转换区, 是溶解物质在地球化学循环与生物体系之间进 行耦合作用的最初场所, 也是水生生态系统物质循环不可缺少的环节. N、P 等生源要素在湖泊水一沉积物界 面及其附近发生剧烈的生物地球化学循环, 并控制 $\mathrm{N} 、 \mathrm{P}$ 等在上覆水体和沉积物间的物质平衡、形态转化和 沉积剖面分布等 ${ }^{[1]}$. 湖泊中磷在生物地球化学循环中, 其中沉积物中的磷与水体中的磷相比, 潜在的磷源是 相对巨大的 ${ }^{[2]}$. 影响沉积物中磷释放的因素有很多, 除温度、 $\mathrm{pH}$ 、溶解氧水平、界面的氧化还原状况、微生物、 底泥磷形态和水体扰动之外 ${ }^{[3-6]}$, 还有沉积物与上覆水磷浓度梯度差、湖泊水化学组成、水生生物、有机质含 量及类型、盐度 ${ }^{[7-9]}$ 等. 磷的释放同时受多种因素的影响, 多种因素之间也相互影响, 释放量的变化取决于它 们的综合作用 ${ }^{[10]}$.

研究内源磷的释放既有助于评价沉积物中磷的可交换性和生物可利用性, 又有助于了解水环境中磷的 循环过程与再生机制, 为生态环境评价提供科学依据 ${ }^{[11-12]}$. 近年来, 关于滇池沉积物磷释放机制的研究在环 境因素的影响 ${ }^{[13-14]}$ 、释放通量 ${ }^{[15]}$ 等方面较多, 但也存在一定的不足之处, 如较少结合沉积物性质、样点, 多以 一个为代表进行分析等. 本文以滇池全湖 35 个表层沉积物样本为研究对象, 系统分析了上覆水-沉积物中 磷的形态及分布特征, 并从不同磷形态与释放过程的关系出发研究二者的相互影响, 以期揭示滇池磷素在 沉积物一水界面的迁移转化规律, 为控制或削减滇池流域内源磷污染提供理论依据.

\section{1 材料与方法}

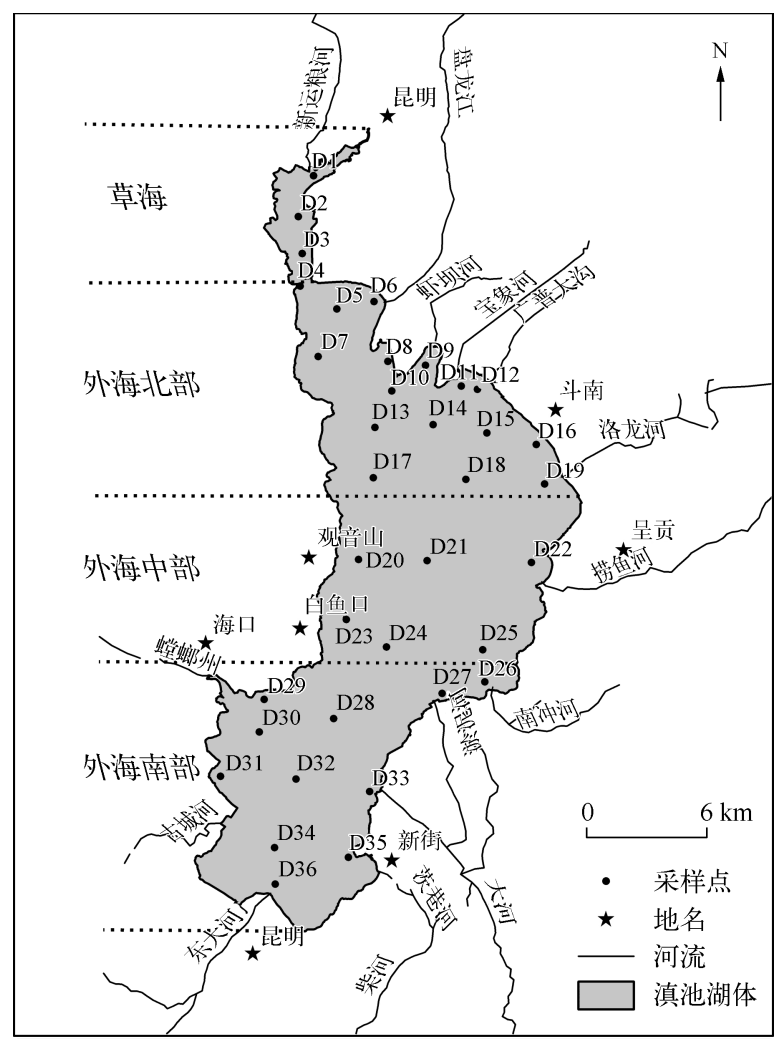

图 1 滇池采样点分布

Fig. 1 Location of sampling sites in Lake Dianchi

\section{1 研究区概况}

滇池位于我国西南部的云贵高原, 是云 南省面积最大的高原湖泊,也是我国第 6 大淡 水湖泊 ${ }^{[16]}$. 滇池是一个典型的断陷构造湖泊, 海拔 $1990 \mathrm{~m}$, 湖面面积 $309.5 \mathrm{~km}^{2}$, 蓄水量 $15.7 \times 10^{8} \mathrm{~m}^{3}$, 最大水深 $10.24 \mathrm{~m}$, 平均水深 $4.40 \mathrm{~m}^{[17]}$. 滇池具有水体滞留时间长的特点, 南、西、东三面分布大量寒武纪磷块岩, 磷输 人来源丰富是导致滇池沉积物中磷含量较高 的主要原因. 每年有大量磷通过物理、化学和 生物作用进人滇池, 尤其是近几十年来由于 大规模开采磷矿以及一些磷化工企业废物排 放, 导致进人滇池的磷急剧增加. 仅南部澄 江、晋宁磷矿开采, 每年就有 $1.3 \times 10^{4} \mathrm{t}$ 含磷 泥砂进人滇池, 滇池北部盘龙江流经昆明市, 携带的工业与生活污水也含有相当的磷元 素 ${ }^{[18]}$, 湖泊富营养化严重.

\section{2 样品采集与处理}

用彼得森采泥器于 2013 年 3 月分别在滇 池的草海 $(n=3)$ 、外海北部 $(n=15)$ 、湖心区 $(n=6)$ 和外海南部 $(n=11) 4$ 个湖区采集表 层沉积物, 样点分布见图 1(其中, D4 样点沉 积物层已被疏浚, 未采样). 沉积物样品泥深 控制在 $10 \mathrm{~cm}$ 以内, 装人塑料密封袋后及时送 
回实验室冷冻保存, 待样品完全冷冻后, 放人真空冷冻干燥机进行干燥, 同时采集原位约 $20 \mathrm{~cm}$ 的上覆水.

\section{3 实验方法}

1.3.1 沉积物总磷及磷形态的测定 沉积物中总磷 (TP) 含量用 Ruban 等提出的欧洲标准测试委员会框架 下发展的 SMT 分离方法测定 ${ }^{[19]}$;根据改进的 Psenner 连续提取法 ${ }^{[20]}$ 测定磷形态 (表 1).

\section{表 1 沉积物中不同磷形态连续提取方法}

Tab. 1 Sequential extraction method of phosphorus in sediments

\begin{tabular}{|c|c|c|}
\hline 磷形态 & & 测定方法 \\
\hline \multirow[t]{5}{*}{ 无机磷 (IP) } & 弱吸附态磷 $\left(\mathrm{NH}_{4} \mathrm{Cl}-\mathrm{P}\right)$ & $\begin{array}{l}\text { 称沉积物干样 } 1 \mathrm{~g} \text { 置于 } 100 \mathrm{ml} \text { 离心管中,加人 } 50 \mathrm{ml} 1 \mathrm{~mol} / \mathrm{L} \text { 的 } \mathrm{NH}_{4} \mathrm{Cl} \\
\text { 后提取; }\end{array}$ \\
\hline & 可还原态磷 ( Fe-P) & $\begin{array}{l}\text { 上一步残渣加人 } 50 \mathrm{ml} \mathrm{BD} \text { 溶液 }\left(0.11 \mathrm{~mol} / \mathrm{L} \text { 的 } \mathrm{NaHCO}_{3} \text { 和 } 0.11 \mathrm{~mol} / \mathrm{L}\right. \\
\text { 的保险粉-连二硫酸钠 }) \text { 在 } 40^{\circ} \mathrm{C} \text { 下振荡 } 1 \mathrm{~h} \text { 后提取; }\end{array}$ \\
\hline & 金属氧化物结合态磷 (Al-P) & 上一步残渣加人 $50 \mathrm{ml} 1 \mathrm{~mol} / \mathrm{L}$ 的 $\mathrm{NaOH}$ 于 $25^{\circ} \mathrm{C}$ 下振荡 $16 \mathrm{~h}$ 后提取; \\
\hline & 钲结合态磷( Ca-P) & 上一步残渣加人 $50 \mathrm{ml} 0.5 \mathrm{~mol} / \mathrm{L}$ 的 $\mathrm{HCl}$ 于 $25^{\circ} \mathrm{C}$ 下振荡 $16 \mathrm{~h}$ 后提取; \\
\hline & 残渣态磷 ( Res-P) & 上一步残渣加人 $50 \mathrm{ml} 1 \mathrm{~mol} / \mathrm{L}$ 的 $\mathrm{NaOH}$ 消煮 $2 \mathrm{~h}$ 提取. \\
\hline 有机磷 ( OP) & & 以 TP 和 IP 的差值表示. \\
\hline
\end{tabular}

1.3 .2 上覆水磷形态的测定上覆水中 TP 浓度采用过硫酸钾消解后用钼锑抗分光光度法测定 ${ }^{[21]}$; 溶解性总磷 (DTP) 浓度是将水样经过 $0.45 \mu \mathrm{m}$ 滤膜过滤后, 进行消解测定; 颗粒态磷 (PP) 浓度是指 TP 与 DTP 浓度的差值; 溶 解态无机磷 (DIP) 浓度是将水样经过 $0.45 \mu \mathrm{m}$ 滤膜过滤后直接测定; 溶解态有机磷 (DOP) 浓度用 DTP 与 DIP 浓度 之差表示 ${ }^{[22]}$.

1.3 .3 磷的释放实验 磷的释放实验分为释放动力学和释放潜力实验. 具体方法如图 2.

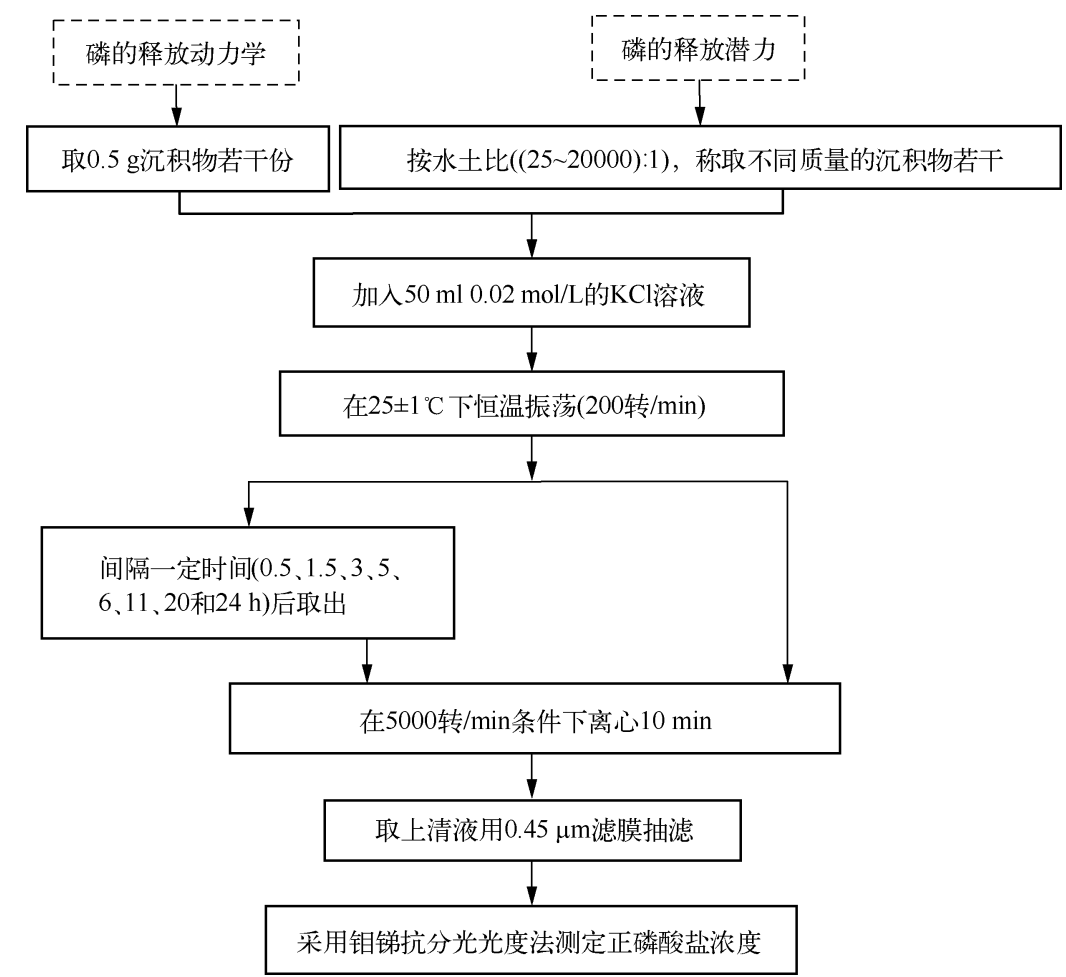

图 2 沉积物中磷的释放实验方法

Fig. 2 The experiment method of release phosphorus in sediments 


\section{2 结果与分析}

\section{1 表层沉积物磷形态分布}

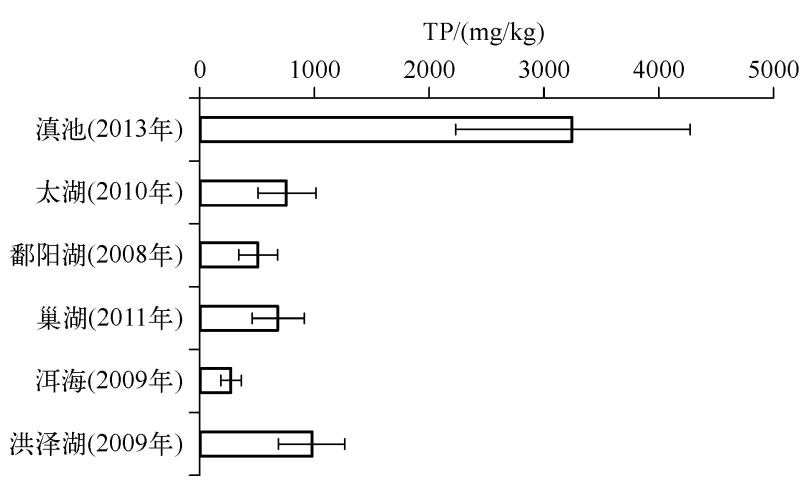

图 3 不同湖泊沉积物中 TP 含量

Fig. 3 The total phosphorus contents of the sediments in different lakes
滇池表层沉积物中 TP 含量介于 $843.96 \sim 8144.44 \mathrm{mg} / \mathrm{kg}$ 之间, 平均值为 $2171.81 \mathrm{mg} / \mathrm{kg}$ (表 2), 与国内其他湖泊相 比 (图 3), 滇池表层沉积物中 TP 含量处 于较高水平, 是其他湖泊的 $3 \sim 12$ 倍左 右 ${ }^{[23-27]}$. 滇池表层沉积物的 TP 含量较高 值出现在草海和外海西南部海口、晋宁附 近区域 (图 4), 前者显然与外源排人有关, 后者与滇池流域的昆阳、海口、尖山、澄江 等大型富磷矿区有关, 其磷矿资源储量约 为 $2.1 \times 10^{9} \mathrm{t}$, 约占全国的 $12 \%$, 近 30 多 年来大规模开采使大量的磷被带人湖 内 $^{[28]}$. 东北部区域是昆明花卉蔬菜的主产 区, 周边土壤 $\mathrm{TP}$ 含量在 $0.50 \sim 7.00 \mathrm{~g} / \mathrm{kg}$

之间, 高于全国土壤平均值 ${ }^{[29]}$, 农业面源的输人加重了沉积物的磷污染; 在湖心区也出现了沉积物中磷的高 值区,这与湖区的“汇集”作用有关 ${ }^{[30]}$.

地球化学形态是判别沉积物中磷的迁移能力、生态效应的重要参数. 化学连续提取法利用不同性质的 化学提取剂, 依次提取出沉积物中某种形态的磷而达到分离目的, 能较好地反映出沉积物磷的生物地球化 学特征 ${ }^{[28]}$. 沉积物中磷的形态决定了其能否参与界面交换和能否为生物所利用 ${ }^{[31]}$, 不同结合态磷含量也反 映了沉积物的磷污染程度和潜在释放能力, 滇池表层沉积物不同形态磷含量表现为: $\mathrm{OP}(1482.49 \pm 1156.82$ $\mathrm{mg} / \mathrm{kg})>\mathrm{Ca}-\mathrm{P}(865.54 \pm 558.40 \mathrm{mg} / \mathrm{kg})>\mathrm{Al}-\mathrm{P}(463.77 \pm 662.18 \mathrm{mg} / \mathrm{kg})>\operatorname{Res}-\mathrm{P}(218.52 \pm 83.11 \mathrm{mg} / \mathrm{kg})>$ Fe-P $(128.13 \pm 101.56 \mathrm{mg} / \mathrm{kg})>\mathrm{NH}_{4} \mathrm{Cl}-\mathrm{P}(2.26 \pm 3.05 \mathrm{mg} / \mathrm{kg})$ (表 2$)$.

滇池表层沉积物中 $\mathrm{NH}_{4} \mathrm{Cl}-\mathrm{P}$ 含量在 $0.69 \sim 14.69 \mathrm{mg} / \mathrm{kg}$ 之间, 约占 TP 含量的 $0.10 \%$ (表 2), 以草海和 外海北部湖区含量较高 (图 4), 由于 $\mathrm{NH}_{4} \mathrm{Cl}-\mathrm{P}$ 主要指被沉积物矿物颗粒表面吸附的磷酸盐, 其含量虽然很 小, 但沉积物产生磷释放时, 首先释放出这部分磷, 并被水生生物吸收利用 ${ }^{[32]}$. Fe-P、Al-P 是指通过物理化学 作用被 $\mathrm{Fe} 、 \mathrm{Al}$ 和 $\mathrm{Mn}$ 的氧化物及其氢氧化物所结合包裹的磷, 该部分磷被认为是生物可以利用的磷, 在厌氧 和碱性条件下的溶解、迁移是其释放的重要机制 ${ }^{[33]}$, 对水一沉积物界面磷的循环起到主要作用 ${ }^{[34]}$, 其受外源 磷输人的影响较大, 来源主要为生活污水、工业废水和部分农业面源流失的磷 ${ }^{[19]}$, 能够反映不同区域磷污染 的状况. 滇池表层沉积物中 Fe-P 和 Al-P 含量分别占 TP 含量的 5.65\% 和 20.45\% (表 2), 以草海和晋宁附 近湖区较高, 海口和呈贡附近湖区较低 (图 4), 最大值和最小值相差 10 倍以上, 其含量的差异体现了人类 活动对不同湖区的影响程度不同. Ca-P 含量占滇池表层沉积物中 TP 含量的 $38.18 \%$ (表 2), 是滇池表层 沉积物中无机磷含量最高的磷形态, 南部晋宁附近湖区沉积物的 Ca-P 含量明显高于其他湖区 (图 4), 这 可能是因为磷肥生产中石膏和酸性磷酸盐的分离导致 Ca-P 形成, 从而进人表层沉积物 ${ }^{[35]}$. Ca-P 一般不易 释放, 但在 $\mathrm{pH}$ 值低、酸度增加时可转化为可溶性磷酸盐 ${ }^{[36]}$, 从而造成湖泊内源污染. Res-P 主要为大分子 有机磷或其他难溶性磷, 大部分会被沉积物埋藏, 难以再生释放出来, 被认为是永久结合态磷, 滇池 (表 层) 沉积物中 Res-P 含量占 TP 含量的 9.64\% (表 2). 湖泊沉积物中 OP 具有部分活性, 大约 $50 \% \sim 60 \%$ 的 $\mathrm{OP}$ 可被降解或水解为生物可利用的磷形态, 是沉积物中重要的 “磷蓄积库”, 对湖泊富营养化具有重要作 用 ${ }^{[37]}$, 其主要来源于农业面源 ${ }^{[38]}$. 滇池表层沉积物中 OP 含量在 830.99 4074.72 $\mathrm{mg} / \mathrm{kg}$ 之间, 占 TP 含 量的 $25.98 \%$ (表 2), 其中以滇池草海湖区最高, 南部湖区次之(图 4), 这与滇池流域人口及工农业布局情 况相符. 

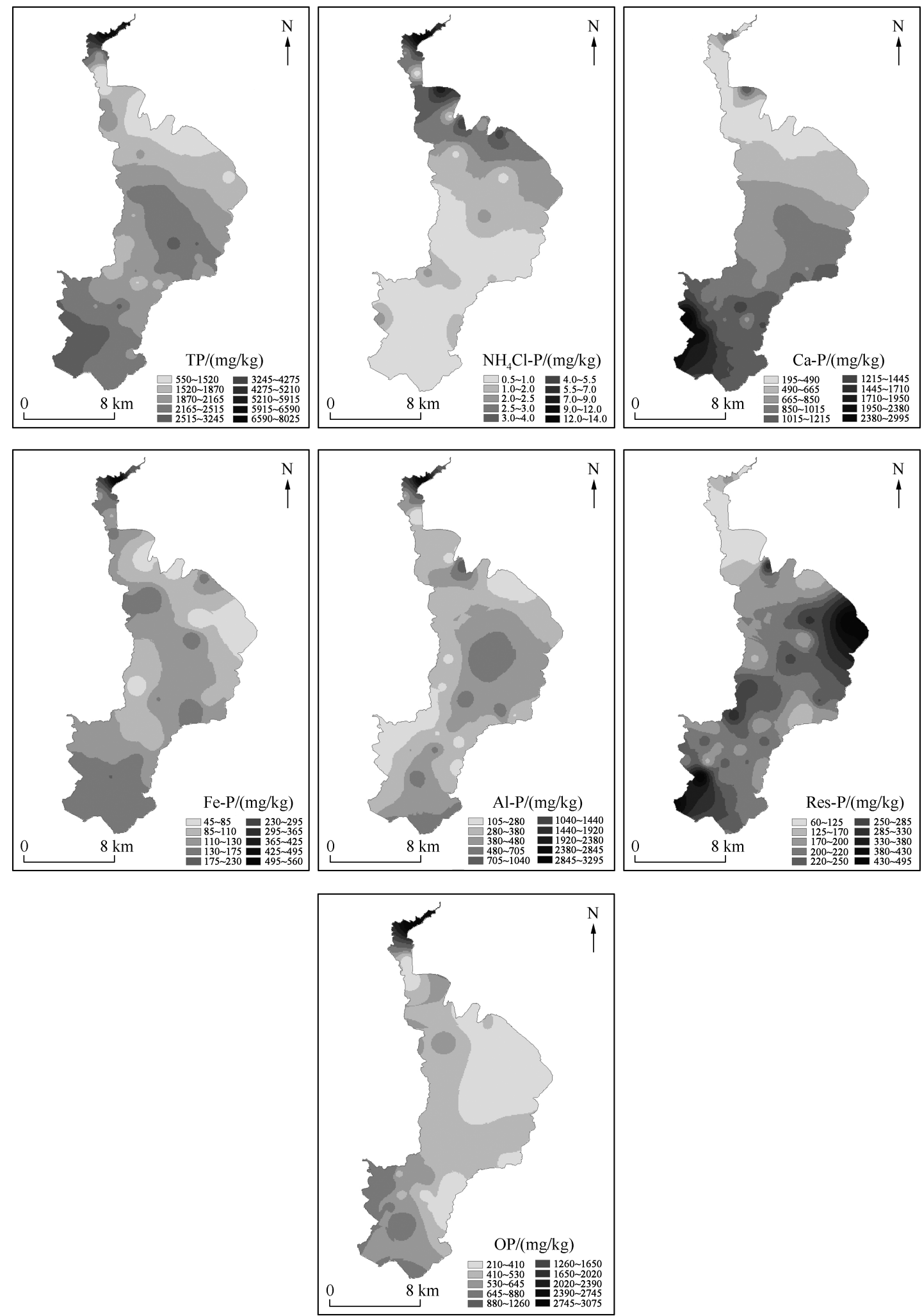

图 4 滇池表层沉积物不同形态磷的空间分布

Fig. 4 Spatial distribution of different forms of phosphorus in surface sediment of Lake Dianchi 
表 2 滇池表层沉积物中不同形态磷的含量

Tab. 2 The contents of different forms of phosphorus in the surface sediment in Lake Dianchi

\begin{tabular}{cccccc}
\hline 磷形态 & 最小值 $/(\mathrm{mg} / \mathrm{kg})$ & 最大值 $/(\mathrm{mg} / \mathrm{kg})$ & 平均值 $/(\mathrm{mg} / \mathrm{kg})$ & 标准差 $/(\mathrm{mg} / \mathrm{kg})$ & 所占 $\mathrm{TP}$ 比例 $/ \%$ \\
\hline $\mathrm{TP}$ & 1596.25 & 5558.50 & 3248.22 & 1020.54 & - \\
$\mathrm{NH}_{4} \mathrm{Cl}-\mathrm{P}$ & 0.69 & 14.69 & 2.26 & 3.05 & 0.07 \\
$\mathrm{Fe}-\mathrm{P}$ & 46.33 & 559.87 & 128.13 & 101.56 & 4.05 \\
$\mathrm{Al}-\mathrm{P}$ & 103.98 & 3295.92 & 463.77 & 662.18 & 14.68 \\
$\mathrm{Ca}-\mathrm{P}$ & 193.80 & 2998.30 & 865.54 & 558.40 & 27.39 \\
Res-P & 78.72 & 496.30 & 218.52 & 83.11 & 6.91 \\
$\mathrm{OP}$ & 830.99 & 4074.72 & 1482.49 & 1156.82 & 46.90 \\
\hline
\end{tabular}

\section{2 上覆水磷形态分布}

沉积物中潜在的磷与水体相比是巨大的,这表明少量磷的释放就会对上覆水水质产生明显的影响. 通 常情况下, 沉积物和上覆水间磷酸盐的交换会达到一个动态平衡, 当环境条件变化时会形成新的界面平衡, 在这个过程中会导致沉积物磷吸附或释放. 天然水体中磷的主要来源是含磷矿物 (如碳酸钲磷矿、磷灰石 等) 的侵蚀溶解作用和人类活动的排放 (如农业灌溉、城市废水、工业污水、畜牧业养殖等). 一般认为当水体 中磷浓度在 $0.02 \mathrm{mg} / \mathrm{L}$ 以上时, 对水体的富营养化就会产生明显的促进作用. 湖泊水体中的大部分磷以 DOP 和 PP 的形式存在, 后者占 TP 的绝大部分 ${ }^{[39]}$.

对比我国《地表水环境质量标准》(GB 3838-2002), 滇池上覆水 TP 浓度在 $0.09 \sim 0.70 \mathrm{mg} / \mathrm{L}$ 之间 (表 3 ), 其中, 草海 TP 浓度处于劣 $\mathrm{V}$ 类水平 $(\geqslant 0.2 \mathrm{mg} / \mathrm{L})$, 外海不同湖区 TP 浓度介于 $\mathrm{IV} \sim \mathrm{V}$ 类之间 $(0.10 \sim$ $0.20 \mathrm{mg} / \mathrm{L}$ ), 以湖心区最低, 外海北部和南部湖区较高 (图 5). DTP 指溶于水中, 且能通过 $0.45 \mu \mathrm{m}$ 微孔滤 膜的磷, 根据理化性质, 可再细分为 DIP 和 $\mathrm{DOP}^{[40]}$. 滇池上覆水中 DTP 浓度在 $0.01 \sim 0.11 \mathrm{mg} / \mathrm{L}$ 之间, 平均 值为 $0.03 \mathrm{mg} / \mathrm{L}$ (表 3), 分布特征与 $\mathrm{TP}$ 十分相似, 以草海和外海北部较高为主要分布特点 (图 5); DIP 能直 接被藻类所利用, 对湖泊初级生产力有重要的影响, 滇池上覆水中 DIP 浓度为 $0 \sim 0.09 \mathrm{mg} / \mathrm{L}$, 平均值为 0.02 $\mathrm{mg} / \mathrm{L}$ (表 3), 湖心区和外海南部的中心区域 DIP 浓度处于较低水平 ( $\leqslant 0.005 \mathrm{mg} / \mathrm{L}$ ) (图 5 ); 浮游植物细 胞被食植动物所消耗, 浮游动物的排泄为 DOP 的主要来源, DOP 是一种不容易被生物所利用的磷形 态 ${ }^{[41]}$, 滇池 DOP 浓度在 $0 \sim 0.04 \mathrm{mg} / \mathrm{L}$ 之间, 平均值为 $0.01 \mathrm{mg} / \mathrm{L}($ 表 3$)$, 以草海和外海南部的中心区域 浓度较高 (图 5); PP 是指存在于水体中的、因吸附作用存在于固体颗粒物表面或内部的颗粒态磷形态, 它 通常以粒子运动方式进行运输, 虽然 PP 通常不能被生物区系直接吸收利用, 但是从长远来看它又会对 水体富营养化有一定的贡献 ${ }^{[42]}$, 并受水体微环境和物化性质的影响很大. 滇池水体中以 PP 浓度最高, 占 TP 浓度的 $67.61 \%$, 其浓度为 $0.05 \sim 0.62 \mathrm{mg} / \mathrm{L}$, 平均值为 $0.13 \mathrm{mg} / \mathrm{L}$ (表 3 ), 滇池水体中 $\mathrm{PP}$ 在人 湖河口(如新运粮河、盘龙江、广普大沟、南冲河、柴河, 这些河流几乎同时兼有农灌、泄洪、纳污等功 能) 区域含量较高 (图 5), 其主要与有机物颗粒结合, 是河流系统和河口地区磷的主要存在形态 ${ }^{[43]}$.

\section{表 3 滇池上覆水中不同形态磷浓度}

Tab. 3 The concentrations of different forms of phosphorus in overlying water of the Lake Dianchi

\begin{tabular}{cccccc}
\hline 磷形态 & 最小值 $/(\mathrm{mg} / \mathrm{L})$ & 最大值 $/(\mathrm{mg} / \mathrm{L})$ & 平均值 $/(\mathrm{mg} / \mathrm{L})$ & 标准差 $/(\mathrm{mg} / \mathrm{L})$ & 所占 TP 比例 $/ \%$ \\
\hline TP & 0.09 & 0.70 & 0.16 & 0.10 & - \\
DTP & 0.01 & 0.11 & 0.03 & 0.02 & 16.20 \\
DIP & 0 & 0.09 & 0.02 & 0.02 & 8.71 \\
DOP & 0 & 0.04 & 0.01 & 0.01 & 7.48 \\
PP & 0.05 & 0.62 & 0.13 & 0.09 & 67.61 \\
\hline
\end{tabular}

\section{3 表层沉积物磷的释放动力学特征}

磷的释放是一个复杂的动力学过程, 由快反应和慢反应两部分组成. 通常前一阶段快反应和慢反应同时 

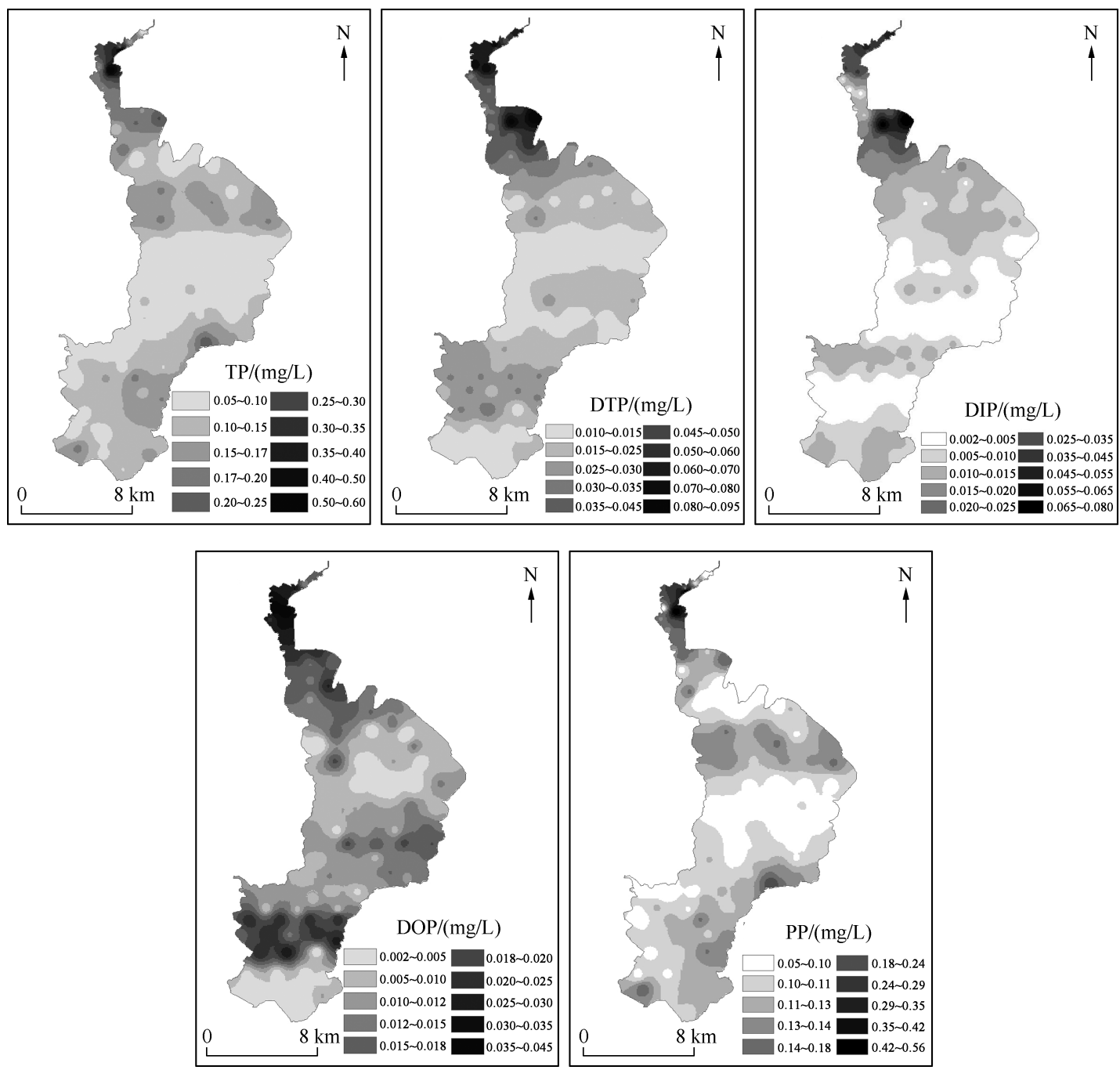

图 5 滇池上覆水不同形态磷浓度的空间分布

Fig. 5 Spatial distribution of different forms of phosphorus concentrations in overlying water of Lake Dianchi 进行, 释放量增加较快, 后一阶段以慢反应为主, 释放量逐渐趋于平衡并达到最大 ${ }^{[44]}$. 滇池表层沉积物对磷 的释放过程主要发生在前 $8 \mathrm{~h}$ 内, 各样点沉积物磷的释放量较大, 曲线较陡; 随着时间的延长, 曲线逐渐呈平 缓的趋势, 基本在 $15 \mathrm{~h}$ 后, 释放量及释放速率随时间的变化不明显, 基本趋近于 0 , 释放逐渐达到动态平 衡(图 6).

为了进一步研究沉积物中磷释放的动力学特征, 引入释放速率 (单位时间、单位质量的沉积物中磷的释 放量) 的概念 ${ }^{[45]}$. 滇池表层沉积物磷在 $0 \sim 0.5 \mathrm{~h}$ 之内释放速率最大, 为 $0.08 \sim 7.09 \mathrm{mg} /(\mathrm{kg} \cdot \mathrm{h})$, 平均值为 $1.56 \mathrm{mg} /(\mathrm{kg} \cdot \mathrm{h})$; 在 $0.5 \mathrm{~h}$ 之后释放速率逐渐降低, 与 $0.5 \mathrm{~h}$ 之内的释放速率相差较大; $4 \mathrm{~h}$ 之内是一快速 反应, $15 \mathrm{~h}$ 之后释放速率很小, 且在此之后时间段的释放速率很接近, 呈动态稳定的状态 (表 4 ). 所以, 滇池 表层沉积物释磷的快反应过程在前 $0.5 \mathrm{~h}$ 之内完成, 慢反应过程延迟至 $15 \mathrm{~h}, 15 \mathrm{~h}$ 内基本完成释放. 滇池不 同区域表层沉积物磷的最大释放速率表现为: 草海 $(2.22 \pm 1.03 \mathrm{mg} /(\mathrm{kg} \cdot \mathrm{h}))>$ 外海北部 $(2.06 \pm 1.96 \mathrm{mg} /$ $(\mathrm{kg} \cdot \mathrm{h}))>$ 外海南部 $(0.72 \pm 0.42 \mathrm{mg} /(\mathrm{kg} \cdot \mathrm{h}))>$ 湖心区 $(0.37 \pm 0.32 \mathrm{mg} /(\mathrm{kg} \cdot \mathrm{h}))$. 

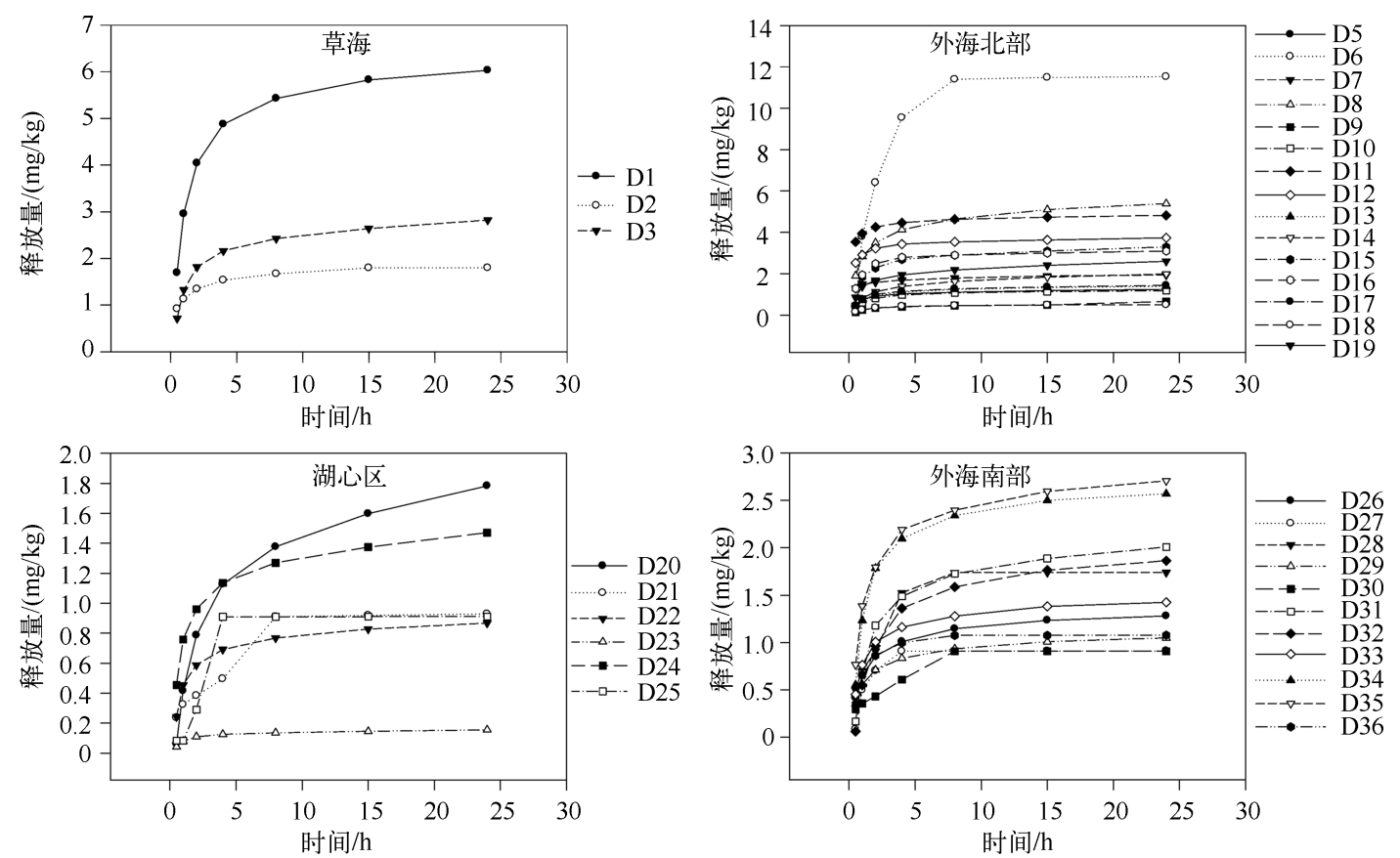

图 6 滇池表层沉积物磷的释放动力学曲线

Fig. 6 The release kinetic curve of phosphorus in the surface sediments of Lake Dianchi

表 4 滇池表层沉积物不同时间段磷的释放速率

Tab. 4 The release rate of phosphorus in surface sediments of Lake Dianchi in different intervals

\begin{tabular}{|c|c|c|c|c|c|c|c|c|}
\hline \multirow{2}{*}{ 湖区 } & \multirow{2}{*}{ 统计量 } & \multicolumn{7}{|c|}{ 时间段/h } \\
\hline & & $0 \sim 0.5$ & $0.5 \sim 1$ & $1 \sim 2$ & $2 \sim 4$ & $4 \sim 8$ & $8 \sim 15$ & $15 \sim 24$ \\
\hline \multirow[t]{4}{*}{ 草海 } & 最小值 $/(\mathrm{mg} /(\mathrm{kg} \cdot \mathrm{h}))$ & 1.43 & 0.41 & 0.22 & 0.09 & 0.03 & 0.02 & 0 \\
\hline & 最大值 $/(\mathrm{mg} /(\mathrm{kg} \cdot \mathrm{h}))$ & 3.39 & 2.53 & 2.53 & 1.09 & 0.42 & 0.14 & 0.06 \\
\hline & 平均值 $/(\mathrm{mg} /(\mathrm{kg} \cdot \mathrm{h}))$ & 2.22 & 1.39 & 1.39 & 0.60 & 0.23 & 0.08 & 0.04 \\
\hline & 标准差 $/(\mathrm{mg} /(\mathrm{kg} \cdot \mathrm{h}))$ & 1.03 & 1.07 & 0.44 & 0.17 & 0.05 & 0.02 & 0.01 \\
\hline \multirow[t]{4}{*}{ 外海北部 } & 最小值 $/(\mathrm{mg} /(\mathrm{kg} \cdot \mathrm{h}))$ & 0.29 & 0.21 & 0.09 & 0.03 & 0.01 & 0 & 0 \\
\hline & 最大值 $/(\mathrm{mg} /(\mathrm{kg} \cdot \mathrm{h}))$ & 7.09 & 6.85 & 2.60 & 1.58 & 0.46 & 0.07 & 0.03 \\
\hline & 平均值 $/(\mathrm{mg} /(\mathrm{kg} \cdot \mathrm{h}))$ & 2.06 & 1.18 & 0.44 & 0.21 & 0.07 & 0.02 & 0.01 \\
\hline & 标准差 $/(\mathrm{mg} /(\mathrm{kg} \cdot \mathrm{h}))$ & 1.96 & 1.63 & 0.62 & 0.39 & 0.11 & 0.02 & 0.01 \\
\hline \multirow[t]{4}{*}{ 湖心区 } & 最小值 $/(\mathrm{mg} /(\mathrm{kg} \cdot \mathrm{h}))$ & 0.08 & 0 & 0.03 & 0.01 & 0 & 0 & 0 \\
\hline & 最大值 $/(\mathrm{mg} /(\mathrm{kg} \cdot \mathrm{h}))$ & 0.91 & 0.71 & 0.37 & 0.31 & 0.10 & 0.03 & 0.02 \\
\hline & 平均值 $/(\mathrm{mg} /(\mathrm{kg} \cdot \mathrm{h}))$ & 0.37 & 0.33 & 0.17 & 0.11 & 0.04 & 0.01 & 0.01 \\
\hline & 标准差 $/(\mathrm{mg} /(\mathrm{kg} \cdot \mathrm{h}))$ & 0.32 & 0.29 & 0.12 & 0.11 & 0.04 & 0.01 & 0.01 \\
\hline \multirow[t]{4}{*}{ 外海南部 } & 最小值 $/(\mathrm{mg} /(\mathrm{kg} \cdot \mathrm{h}))$ & 0.12 & 0.12 & 0.08 & 0.06 & 0 & 0 & 0 \\
\hline & 最大值 $/(\mathrm{mg} /(\mathrm{kg} \cdot \mathrm{h}))$ & 1.53 & 1.36 & 0.55 & 0.31 & 0.07 & 0.03 & 0.01 \\
\hline & 平均值 $/(\mathrm{mg} /(\mathrm{kg} \cdot \mathrm{h}))$ & 0.72 & 0.73 & 0.29 & 0.14 & 0.04 & 0.01 & 0.01 \\
\hline & 标准差 $/(\mathrm{mg} /(\mathrm{kg} \cdot \mathrm{h}))$ & 0.42 & 0.38 & 0.15 & 0.08 & 0.02 & 0.01 & 0.01 \\
\hline
\end{tabular}

为定量分析沉积物磷的释放动力学过程, 采用一级动力学方程 ${ }^{[46]}$ 进行拟合: $Q_{t}=Q_{\text {max }} \cdot\left(1-\mathrm{e}^{-k t}\right)$. 式 中, $Q_{t}$ 为 $t$ 时刻磷的释放量 (以干质量计, 下同) $(\mathrm{mg} / \mathrm{kg}) ; Q_{\max }$ 为释放平衡时磷的释放量 (即最大释放量) $(\mathrm{mg} / \mathrm{kg}) ; k$ 为磷的释放速率常数; $t$ 为释放时间 ( $\mathrm{min})$. 一级动力学方程很好地拟合了滇池表层沉积物释磷 的动力学过程, $R^{2}>0.70$, 达到显著相关水平 $(P<0.05)$. $Q_{\text {max }}$ 表示本研究条件下沉积物磷的释放能力, 也是 
沉积物磷释放动力学特征的重要参数 ${ }^{[47]}$. 滇池表层沉积物中磷的 $Q_{\text {max }}$ 介于 $0.14 \sim 11.76 \mathrm{mg} / \mathrm{kg}$ 之间, 平均 值为 $2.12 \mathrm{mg} / \mathrm{kg}$. 不同区域表层沉积物磷的 $Q_{\max }$ 平均值表现为草海 $(3.32 \pm 2.10 \mathrm{mg} / \mathrm{kg})>$ 外海北岸 $(2.83 \pm 2.82$ $\mathrm{mg} / \mathrm{kg})>$ 外海南岸 $(1.43 \pm 0.50 \mathrm{mg} / \mathrm{kg})>$ 湖心区 $(0.99 \pm 0.52 \mathrm{mg} / \mathrm{kg})$, 其分布情况与最大释放速率 $\left(V_{\max }\right)$ 相 同. 由于草海植物生长较其它湖区茂盛,植物死亡所产生的生物残体也就较其它湖区多, 碎屑在湖底分解往 往不能彻底进行, 残存物将随泥沙沉降而被层叠式掩埋, 在表层仍能进行好氧分解, 下层则会产生自上而下 的缺氧和厌氧环境. 在微生物作用下, 向水体中析出游离态 $\mathrm{PO}_{4}^{3-}$ 离子 ${ }^{[48]}$; 其次, 草海和外海北部是较多人湖 河道的受纳区域,新运粮河、宝象河、盘龙江等人湖河流流量较大, 且兼顾农灌、泄洪、纳污等功能,表层底泥 接纳来自外部污染性颗粒物沉降的机会较其它湖区高, 在生物矿化和化学转化等作用下, 游离态磷 (通常为 正磷酸盐 $\left.\left(\mathrm{PO}_{4}^{3-}-\mathrm{P}\right)\right)$ 被不断分解出来,进人并溶存于沉积物间隙水中, 在表层沉积物物性决定的阻碍层两 侧, 与上覆水 $\mathrm{PO}_{4}^{3-}-\mathrm{P}$ 浓度形成浓度梯度, 进行着与环境条件 (如温度) 相适应的并遵守分子扩散定律的磷界 面的释放 ${ }^{[49]}$; 再次, 湖心区相对远离陆源, 因此沉积物中 TP 和有机质含量较其它湖区偏低, 再加上该区域湖 面开敞, 水动力作用影响大,因此表层沉积物的分选程度较好, 有机质矿化作用将较显著, 无机矿物颗粒成 分应有较高比例. 在相对平静的环境中, 表层沉积物在一定时段内吸收上覆水中的 $\mathrm{PO}_{4}^{3-}-\mathrm{P}$, 以致形成内汇, 磷的释放作用降低 ${ }^{[50]}$.

与不同湖泊沉积物相比, 滇池沉积物中 磷的 $V_{\text {max }}$ 和 $Q_{\text {max }}$ 处于较低水平 ${ }^{[51]}$ (表 5 ). 当 湖泊沉积物中金属含量 $\mathrm{Ca} /(\mathrm{Fe}+\mathrm{Al})>0.7$ 时, 为钙质沉积物 ${ }^{[52]}$. 滇池沉积物中 $\mathrm{Ca} /$ $(\mathrm{Fe}+\mathrm{Al})$ 为 $0.78 \sim 1.46$, 表明滇池沉积物为 典型的钙质沉积物. 滇池年平均温度约为 $17^{\circ} \mathrm{C}$, 水体 $\mathrm{pH}$ 为 $7.59 \sim 8.80$. 因此, 滇池湖 内正磷酸盐被吸附到 $\mathrm{CaCO}_{3}$ 沉淀上或者与 $\mathrm{CaCO}_{3}$ 沉淀发生共沉淀,共沉淀的作用随着温 度和 $\mathrm{pH}$ (在 $8.0 \sim 10.0$ 范围内) 的增加而加 强 ${ }^{[53]}$, 这个自然机制阻碍了滇池沉积物中 IP

表 5 不同湖泊沉积物中磷的最大释放速率和最大释放量

Tab. 5 The maximum release rate and quantity of phosphorus in sediments of different lakes

\begin{tabular}{ccc}
\hline 湖泊 & $V_{\max } /(\mathrm{mg} /(\mathrm{kg} \cdot \mathrm{h}))$ & $Q_{\max } /(\mathrm{mg} / \mathrm{kg})$ \\
\hline 滇池 & 1.34 & 2.12 \\
鄱阳湖 & 0.24 & 590.00 \\
东湖 & 2.34 & 773.10 \\
洪泽湖 & 1.27 & 714.30 \\
太湖 & 1.15 & 488.53 \\
玄武湖 & 3.59 & 666.70 \\
\hline
\end{tabular}
含量较高的 Ca-P 的释放.

\section{4 表层沉积物磷的释放潜力}

本实验对沉积物释放潜力的测定采用的是一步浸提法, 即在 $1: 100$ 的沉积物和水的比值下磷的释放 量 ${ }^{[54]}$. 水土比不同, 沉积物一水界面磷的平衡浓度也不同,一般来讲,水土比越大越有利于沉积物磷的释放. 因此, 可以采用无限稀释法测定沉积物磷的释放潜力 (IDE-P). 滇池表层沉积物中磷的释放量随着水土质量 比的增加而增加, 水土质量比约为 20000 时, 磷释放量基本达到最大值, 水土比再增大时, 其磷释放量基本 趋于平衡(图 7). 滇池表层沉积物 IDE-P 介于 $32.64 \sim 419.00 \mathrm{mg} / \mathrm{kg}$ 之间, 不同区域沉积物的 IDE-P 平均值 表现为:草海 $(157.96 \pm 94.11 \mathrm{mg} / \mathrm{kg})>$ 外海北部 $(113.45 \pm 87.64 \mathrm{mg} / \mathrm{kg})>$ 外海南部 $(80.16 \pm$ $33.69 \mathrm{mg} / \mathrm{kg})>$ 湖心区 $(67.17 \pm 30.01 \mathrm{mg} / \mathrm{kg})$, 湖心区由于人类活动较少, 磷含量较低, 其释放潜力相对较 小,而靠近昆明主城区和流经城区的河流人湖口区域的样点由于沉积物 TP 和 PP 含量较高, 污染物释放潜 力相对较高.

\section{5 沉积物 - 上覆水磷形态与磷的释放}

沉积物中不同结合态的磷可以反映不同历史时期磷污染输人特征, 同时具有不同的生物有效性, 可以 间接反映沉积物中磷的释放潜力 ${ }^{[55]}$, 对上覆水体富营养化的发生具有潜在的、不可忽视的影响. 沉积物中磷 的释放机理、释放量与内源的存在形态、金属结合态的转化能力、沉积物一上覆水之间磷元素的交换有关 ${ }^{[56]}$. 底泥中的磷以无机态的 $\mathrm{PO}_{4}^{3-}-\mathrm{P}$ 为主, 一旦出现利于钲、铝、铁等不溶性磷酸盐沉淀物溶解的条件, 磷的释放 就可能发生 ${ }^{[57]}$. 不同地理环境的湖泊磷释放的决定因素存在差别 ${ }^{[58]}$. 滇池表层沉积物中磷的释放主要由 $\mathrm{NH}_{4} \mathrm{Cl}-\mathrm{P} 、 \mathrm{Fe}-\mathrm{P} 、 \mathrm{Al}-\mathrm{P}$ 和 $\mathrm{OP}$ 进行 (表 6), 其中, $\mathrm{NH}_{4} \mathrm{Cl}-\mathrm{P}$ 和 Fe-P 所占比重较大. $\mathrm{NH}_{4} \mathrm{Cl}-\mathrm{P}$ 是较容易释放的磷, $\mathrm{Fe}-\mathrm{P}$ 几乎都具有活性, 并且在还原环境下几乎可以全部释放, 这进一步说明 Fe-P 极其不稳定. 另外, 当氧化 

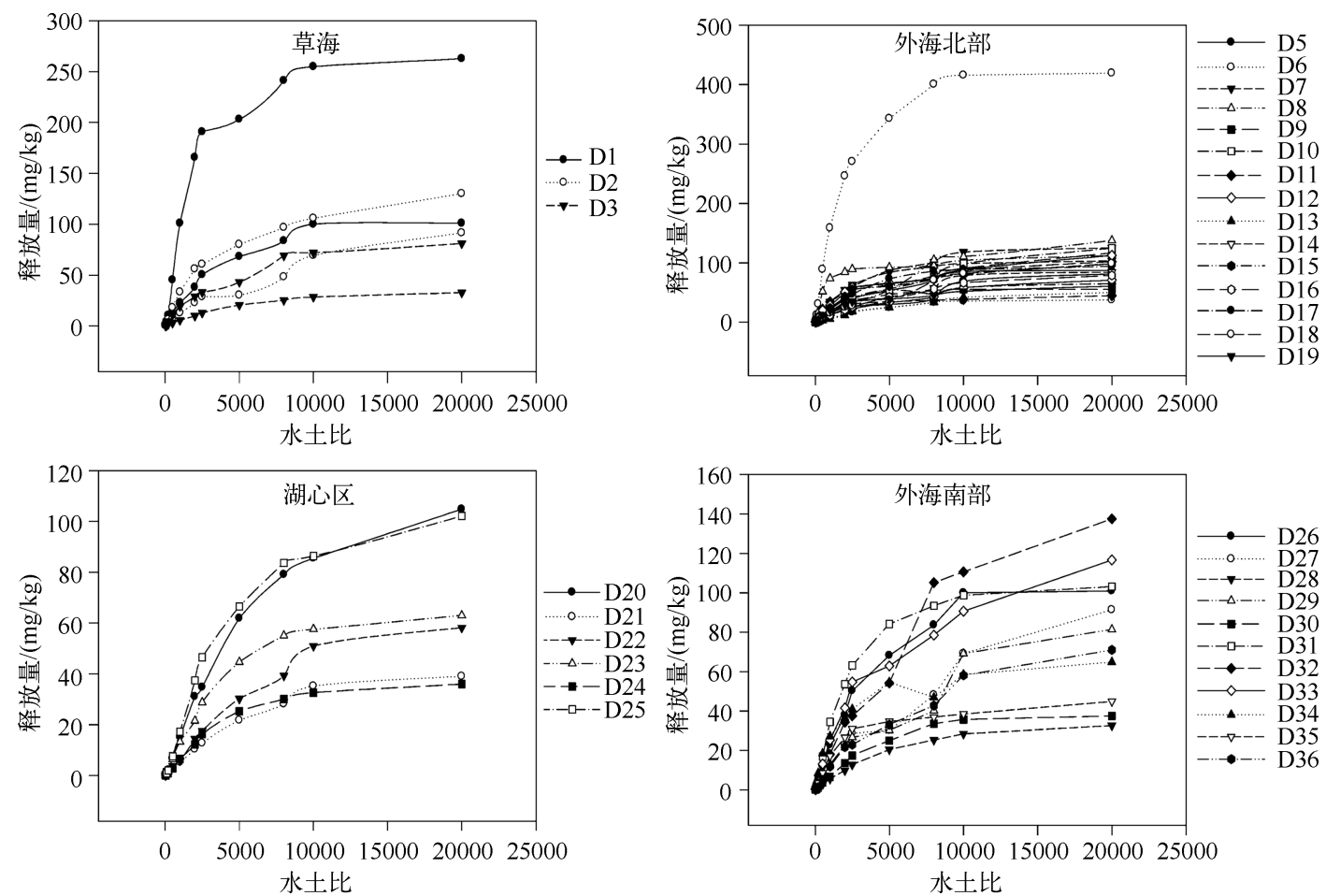

图 7 滇池表层沉积物中磷释放量随水土质量比的变化

Fig. 7 The changes of the maximal release potential of phosphorus in surface sediment of Lake Dianchi with the ratios of water to soil

表 6 滇池表层沉积物磷的释放特征参数 与不同磷形态之间的相关性

Tab. 6 Correlation of different forms of phosphorus with the release of phosphorus characteristic parameters in surface sediment of Lake Dianchi

\begin{tabular}{|c|c|c|c|c|}
\hline & 参数 & $V_{\max }$ & $Q_{\max }$ & IDE-P \\
\hline \multirow[t]{7}{*}{ 沉积物 } & $\mathrm{TP}$ & -0.2840 & -0.0920 & 0.3504 \\
\hline & $\mathrm{NH}_{4} \mathrm{Cl}-\mathrm{P}$ & $0.5459^{*}$ & $0.8001^{* *}$ & $0.7855^{* *}$ \\
\hline & $\mathrm{Fe}-\mathrm{P}$ & 0.2635 & $0.5659^{* *}$ & $0.7638^{* *}$ \\
\hline & Al-P & 0.0516 & 0.3907 & $0.7357^{* *}$ \\
\hline & Ca-P & -0.1795 & -0.1502 & 0.1555 \\
\hline & Res-P & -0.1680 & -0.0696 & -0.2054 \\
\hline & $\mathrm{OP}$ & 0.2650 & $0.6320^{*}$ & $0.5790^{*}$ \\
\hline \multirow[t]{5}{*}{ 上覆水 } & $\mathrm{TP}$ & 0.1449 & 0.1597 & 0.3207 \\
\hline & DTP & $0.4908 * *$ & $0.6049^{* *}$ & $0.7215^{* * *}$ \\
\hline & DIP & $0.5289^{* *}$ & $0.6527^{* *}$ & $0.7063^{* *}$ \\
\hline & DOP & 0.1544 & 0.1879 & $0.3907^{*}$ \\
\hline & PP & 0.0223 & 0.0054 & 0.1565 \\
\hline
\end{tabular}

**表示 $P<0.01, *$ 表示 $P<0.05$.
还原电位和盐度降低时, Fe-P 会被活化而进 人水体, 这部分磷或被生物利用, 或与水体中 其他离子 $\left(\mathrm{Ca}^{2+} 、 \mathrm{Al}^{3+}\right)$ 相结合, 因此当沉积物 中 $\mathrm{Fe} 、 \mathrm{Al} 、 \mathrm{Ca}$ 等含量由于人为污染等因素发 生改变时, 磷就会在不同形态间进行释放和 重新组合, 从而实现不同形态磷间的转化.

$\mathrm{PO}_{4}^{3-}-\mathrm{P}$ 被认为是 DTP 中最易被生物利 用的磷形态, 也称作生物可利用磷, 可作为研 究湖泊富营养化状态的参数, 并随着岩石的 自然分化、溶解、土壤的淋溶和迁移, 以及生 物转化等过程进人水体 ${ }^{[59]}$. 磷的释放与上覆 水中 DTP、DIP 和 DOP 浓度呈显著正相关 $(P<0.05)$ (表 6), 预示着上覆水中磷的迁移 转化更多地受到水一沉积物界面浓度梯度的 控制, 进一步说明不能以 TP 含量来评价湖泊 磷素释放的状况, 需与磷形态及分布特征相 结合进行分析.

\section{3 结论}

滇池表层沉积物中 TP 含量介于 843.96 
$8144.44 \mathrm{mg} / \mathrm{kg}$ 之间, 是其他湖泊的 $3 \sim 12$ 倍左右, 处于较高水平; 不同形态磷含量表现为: OP (1482. $49 \pm$ $1156.82 \mathrm{mg} / \mathrm{kg})>\mathrm{Ca}-\mathrm{P}(865.54 \pm 558.40 \mathrm{mg} / \mathrm{kg})>\mathrm{Al}-\mathrm{P}(463.77 \pm 662.18 \mathrm{mg} / \mathrm{kg})>\operatorname{Res}-\mathrm{P}(218.52 \pm$ $83.11 \mathrm{mg} / \mathrm{kg})>\mathrm{Fe}-\mathrm{P}(128.13 \pm 101.56 \mathrm{mg} / \mathrm{kg})>\mathrm{NH}_{4} \mathrm{Cl}-\mathrm{P}(2.26 \pm 3.05 \mathrm{mg} / \mathrm{kg})$.

滇池表层上覆水中 TP 浓度在 $0.09 \sim 0.70 \mathrm{mg} / \mathrm{L}$ 之间, 草海水质为劣 $\mathrm{IV}$ 类, 外海不同湖区水质介于 $\mathrm{IV} \sim$ $\mathrm{V}$ 类之间; 滇池上覆水中磷浓度以 PP 最高, 占 TP 浓度的 $67.61 \%$, 在人湖河流河口处(如新运粮河、盘龙江、 广普大沟、南冲河、柴河)浓度较高, 长远看来对水体富营养化有一定的贡献.

滇池沉积物磷的释放过程主要发生在前 $8 \mathrm{~h}$ 内; 不同区域沉积物磷的 $V_{\text {max }} 、 Q_{\text {max }}$ 和 IDE-P 平均值均表现 为: 草海 $>$ 外海北部 $>$ 外海南部 > 湖心区; 滇池表层沉积物中磷的释放主要由 $\mathrm{NH}_{4} \mathrm{Cl}-\mathrm{P} 、 \mathrm{Fe}-\mathrm{P} 、 \mathrm{Al}-\mathrm{P}$ 和 OP 进 行, 其中, $\mathrm{NH}_{4} \mathrm{Cl}-\mathrm{P}$ 和 Fe-P 所占比重较大; 磷的释放与上覆水中 DTP、DIP 和 DOP 浓度呈显著正相关 $(P<$ $0.05)$, 预示着上覆水中磷的迁移转化更多地受到水一沉积物界面浓度梯度的控制, 进一步说明不能以 TP 含 量来评价湖泊磷素释放的状况,需与磷形态及分布特征相结合分析.

致谢: 感谢中国环境科学研究院湖泊生态环境创新基地的焦立新博士在本文完成期间提供的帮助.

\section{4 参考文献}

［1］李 宝,丁士明,范成新等. 滇池福保湾底泥内源氮磷营养盐释放通量估算. 环境科学, 2008, 29(1):114-120.

[ 2 ] 王雨春, 万国江, 黄荣贵等. 湖泊现代沉积物中磷的地球化学作用及环境效应. 重庆环境科学, 2000,22(4):39-41.

[3] 高 丽,杨 浩,周建民. 湖泊沉积物中磷释放的研究进展.土壤, 2004,36(1):12-15.

[ 4 ] Katsev S, Tsandev I, Heureux IL et al. Factors controlling long-term phosphorus efflux from lake sediments: Exploratory reactive-transport modeling. Chemical Geology, 2006, 234(1/2) : 127-147.

[ 5 ] 尤本胜, 王同城, 范成新等. 太湖沉积物再悬浮模拟方法. 湖泊科学, 2007, 19 (5):611-617. DOI 10. 18307/ 2007. 0518 .

[ 6 ] 李大鹏,黄 勇. 底泥扰动在水体富营养化发展进程中的作用. 中国给水排水,2009,25(14):10-16.

[ 7 ] Xie LQ, Xie P, Tang HJ. Enhancement of dissolved phosphorus release from sediment to lake water by Microcystis bloomsan enclosure experiment in a hyper-eutrophic, subtropical Chinese lake. Environmental Pollution, 2003, 122 : 391-399.

[ 8 ] 金相灿, 王圣瑞, 庞 燕. 太湖沉积物磷形态及 $\mathrm{pH}$ 值对磷释放的影响. 中国环境科学, 2004,24(6):707-711.

[ 9 ] Jin XC, Wang SR, Pang Y et al. The adsorption of phosphate on different trophic lake sediments. Colloids and Surfaces A, 2005, 254 (1/2/3): 241-248.

[10］董浩平. 城市湖泊底泥污染释放规律及在水质模型中的应用 [学位论文]. 南京: 河海大学,2005:1-63.

[11］吕晓霞,翟世奎,于增慧. 长江口及临近海域表层沉积物中营养元素的分布特征及控制因素. 海洋环境科学,2005, $24(3): 1-5$.

[12] 秦伯强,朱广伟,张 路等. 大型浅水湖泊沉积物内源营养盐释放模式及其估算方法一一太湖为例. 中国科学: D 辑: 地球科学,2005,35(增刊 11):33-34.

[13] 高 丽,杨 浩,周健民. 环境条件变化对滇池沉积物磷释放的影响.土壤,2005,37(2):216-219.

[14] 邓 莎. 环境因素对滇池外海中心沉积物磷释放的影响 [学位论文]. 云南: 昆明理工大学,2013:1-92.

[15] 毛建忠, 王雨春, 赵琼美等. 滇池沉积物内源磷释放初步研究. 中国水利水电科学研究院学报, 2005, 3 (3): 229-233.

[16] Liu JL, Wang RM, Huang B et al. Distribution and bioaccumulation of steroidal and phenolic endocrine disrupting chemicals in wild fish species from Dianchi Lake, China. Environmental Pollution, 2011, 159: 2815-2822.

[17] Wan X, Pan XJ, Wang B et al. Distributions, historical trends, and source investigation of polychlorinated biphenyls in Dianchi Lake, China. Chemosphere, 2011, 85: 361-367.

[18］夏学惠, 东野脉兴, 周建民等. 滇池现代沉积物中磷的地球化学及其对环境影响. 沉积学报,2002,20(3):416-420.

[19] Ruban V, López-Sánchez JF, Pardo P et al. Harmonized protocol and certified reference material for the determination of phosphorus in freshwater sediment-A synthesis of recent works. Fresenius Journal of Analytical Chemistry, 2001, 370 : 224-228.

[20] Kaiserli A, Voutas D, Samara C. Phosphorus fractionation in lake sediments-Lakes Volvi and Koronia, N. Greece. Chemosphere, 2002, 46(8): 1147-1155.

[21] 国家环境保护总局《水和废水监测分析方法》编委会. 水和废水监测分析方法:第 4 版. 北京: 中国环境科学出版 社,2002:246-248.

[22] 李大鹏,王 晶, 黄 勇. 反复扰动下磷在沉积物和悬浮物以及上覆水间的交换. 环境科学, 2013, 34 (6): 
2191-2197.

[23] 杨 洋,刘其根,胡忠军等. 太湖流域沉积物碳氮磷分布与污染评价. 环境科学学报,2014,34(12):28.

[24] 王圣瑞,倪 栋,焦立新等. 鄱阳湖表层沉积物有机质和营养盐分布特征. 环境工程技术学报,2012,2(1):24-28.

[25] 李 强. 巢湖流域氮磷的分布特征及其相关性研究 [学位论文]. 武汉:武汉纺织大学,2013:1-59.

[26] 李延鹏,杨 婕, 肖 文等. 洱海及上游主要湖泊底泥营养盐的研究. 大理学院学报,2013,12(4):58-61.

[27] 杨文澜,蒋功成,王兆群等. 洪泽湖不同湖区表层沉积物中磷的形态和分布特征. 地球与环境, 2013,41(1):43-49.

[28] 刘 超, 朱淮武,王立英等. 滇池与红枫湖沉积物中磷的地球化学特征比较研究. 环境科学学报, 2013,33(4): 1073-1079.

[29］张乃明,李成学,李阳红. 滇池流域土壤磷累积特征与释放风险研究.土壤,2007,39(4):665-667.

[30］史丽琼. 滇池水体及表层沉积物一水界面各形态磷分布特征研究 [ 学位论文].昆明:昆明理工大学,2011:1-77.

[31] 秦伯强,范成新. 大型浅水湖泊内源营养盐释放的概念性模式探讨. 中国环境科学, 2002,22(2):155-153.

[32] 袁 建. 湖泊沉积物中磷形态标准物质研制及环境地球化学行为研究 [ 学位论文]. 北京: 中国地质科学院, 2012: $1-70$.

[33 ] Rydin E. Potentially mobile phosphorus in lake Erken sediment. Water Research, 2000, 34(7) : 2037-2042.

[34] 岳宗凯,马启敏,张亚楠等. 东昌湖表层沉积物的磷赋存形态. 环境化学, 2013,32(2):219-224.

[35] Gao L, Zhou JM, Yang H et al. Phosphorus fractions in sediment profiles and their potential contributions to eutrophication in Dianchi lake. Environmental Geology, 2005, 48(7): 835-844.

[36] 董浩平,姚 琪. 水体沉积物磷释放及控制. 水资源保护, 2004,20(6):20-23.

[37] Zhang RY, Wu FC, Liu CQ et al. Characteristics of organic phosphorus fractions in different trophic sediments of lakes from the middle and lower reaches of Yangtze River region and Southwestern Plateau, China. Environmental Pollution, 2008,152 : 366-372.

[38] 张宪伟,潘 纲,陈 影等. 黄河沉积物磷形态沿程分布特征. 环境科学学报,2009,29(1):191-198.

[39] 孙金华.太湖水体有机磷组成空间分布及与水环境关系 [学位论文]. 郑州: 河南大学, 2013:1-81.

[40] 吴强亮.沉水植物苦草对水环境中磷的影响 [学位论文]. 武汉:华中农业大学,2013:1-61.

[41] 陈洪涛,陈淑珠, 张 经等. 南黄海海水中各种形态磷的分布变化特征. 海洋环境科学,2002,21(1):9-13.

[42] 胡正峰. 加拿大格兰德河水体磷素形态转化及水生生物对磷素吸收释放研究 [学位论文]. 重庆: 西南大学, 2013: $1-149$.

[43] 吴 怡,邓天龙,徐 青等. 水环境中磷的赋存形态及其分析方法研究进展. 盐矿测试,2010,29(5):557-564.

[44] Lee-Hyung K, Euiso C, Michael KS. Sediment characteristics, phosphorus types and phosphorus release rates between river and lake sediments. Chemosphere, 2003, 50: 53-61.

[45] Wang SR, Jin XC, Bu QY et al. Effects of particle size, organic matter content and ionic strength in solution on the phosphate sorption by different trophic lake sediments. Journal of Hazardous Materials, 2006, 128: 95-105.

[46] Hou LJ, Liu M, Jiang HY. Ammonium adsorption by tidal flat surface sediments from the Yangtze Estuary. Environmental Geology, 2003, 45: 72-78.

[47] 晏维金,章 申,唐以剑. 磷在土壤中的解吸动力学. 中国环境科学,2000,20(2):97-101.

[48] 范成新, 张 路, 包先明等. 太湖沉积物一水界面生源要素迁移机制及定量化-2. 磷释放的热力学机制及源一汇 转换. 湖泊科学, 2006,18(3) :207-217. DOI 10.18307/2006. 0303.

[49] 徐轶群. 重庆龙水湖底泥磷的吸附与释放特征研究 [ 学位论文]. 重庆:西南农业大学, 2004:1-53.

[50］范成新,张 路, 杨龙元等. 湖泊沉积物氮磷内源负荷模拟. 海洋与湖沼, 2002,33(4):27-35.

[51] Jin XC, Wang SR, Bu QY. Laboratory experiments on phosphorous release from the sediments of 9 lakes in the middle and lower reaches of Yangtze River region, China. Water, Air, and Soil Pollution, 2006, 176(1/2/3/4) : 233-251.

[52] Ding SM, Bai XL, Fan CX et al. Caution needed in pretreatment of sediments for refining phosphorus-31 nuclear magnetic resonance analysis: Results from a comprehensive assessment of pretreatment with ethylendiaminetetraacetic acid. Journal of Environmental Quality, 2010, 39: 1668-1678.

[53] Hu J, Shen Q, Liu YD et al. Mobility of different phosphorus pools in the sediment of Lake Dianchi during cyanobacterial blooms. Environmental Monitoring Assessment, 2007, 132: 141-153.

[54] 王圣瑞. 湖泊沉积物一水界面过程氮磷生物地球化学. 北京: 科学出版社,2012: 118 .

[55] 黄清辉,王东红,王春霞. 沉积物中磷形态与湖泊富营养化的关系. 中国环境科学, 2003,23(6):583-586.

[56] 王庭健. 城市富营养化湖泊沉积物中磷负荷及其释放对水质的影响. 环境科学研究, 1994,7(4):12-20.

[57] 金相灿,徐南妮,张雨田等.沉积物污染化学. 北京:中国环境科学出版社, 1992 :99.

[58] 谢丽强, 谢 平, 唐汇娟. 武汉东湖不同湖区底泥总磷含量及变化的研究. 水生生物学报, 2001,25(4):305-310.

[59] 赵文伟. 东湖沉积物的磷吸附释放特征及其控制研究 [学位论文]. 武汉:华中科技大学,2007:1-47. 